\title{
The content of certain minerals and trace elements in products made from amaranth and buckwheat flour for children with gluten intolerance
}

\author{
S.A.Urubkov, S.S.Khovanskaya, S.O.Smirnov \\ Scientific Research Institute of Food-concentrate Industry and Special Food Technology - Branch Federal Research \\ Center of Nutrition and Biotechnology and Food safety, Izmailovo, Moscow region, Russian Federation
}

\begin{abstract}
The objective. The purpose of this work was to determine the content of macro- and microelements in buckwheat and amaranth flour, as well as products (pancakes) obtained from flour mixtures of these cultures.

Materials and methods. The content of minerals $(\mathrm{Ca}, \mathrm{Mg}, \mathrm{K}, \mathrm{Na}, \mathrm{Fe}, \mathrm{Cu}, \mathrm{Zn}, \mathrm{Mn}, \mathrm{Se}, \mathrm{Co}, \mathrm{Pb}, \mathrm{Ni}, \mathrm{Mo})$ in buckwheat and amaranth flour, as well as products obtained from flour mixtures of these cultures, was studied. To determine the mineral content in the samples, the method of atomic absorption spectroscopy.

Results. As a result of the conducted research, experimental material was obtained on the content of macro-and microelements in gluten-free products. A significant part of the minerals of the flour samples under consideration is potassium $-371 \mathrm{mg} / 100 \mathrm{~g}$ for amaranth flour and $405 \mathrm{mg} / 100 \mathrm{~g}$ for buckwheat flour. High magnesium content was found in buckwheat flour $239.9 \mathrm{mg} / 100$ $\mathrm{g}$ and $202.5 \mathrm{mg} / 100 \mathrm{~g}$ in amaranth flour. Low calcium content was observed in both samples: $69.0 \mathrm{mg} / \mathrm{kg}$ in amaranth and 62.0 $\mathrm{mg} / \mathrm{kg}$ in buckwheat flour. Amaranth flour is superior to buckwheat flour in the content of trace elements such as copper (319 $\mathrm{mcg} / 100 \mathrm{~g})$, zinc $(2495 \mathrm{mcg} / 100 \mathrm{~g})$ and selenium $(515.4 \mathrm{mcg} / 100 \mathrm{~g})$. Buckwheat flour contains more potassium $(405.9 \mathrm{mg} / 100$ $\mathrm{g})$, magnesium $(239.9 \mathrm{mg} / 100 \mathrm{~g})$, and copper $(334 \mathrm{mcg} / 100 \mathrm{~g})$ than amaranth flour. The data obtained show that amaranth and buckwheat flour can be classified as good sources of selenium with a content of $515.4 \mathrm{mcg} / 100 \mathrm{~g}$ and $404.0 \mathrm{mcg} / 100 \mathrm{~g}$, respectively. The content of mineral substances in pancakes made from mixtures of amaranth flour and native buckwheat flour decreased within 3-23\% of their content in the original flour. The calculation of the recommended daily requirement showed that the use of a portion of pancakes $(45 \mathrm{~g})$ by school-age children will meet their daily needs on average: in magnesium by $35.3 \%$, in potassium by $9.5 \%$, in iron by $26.4 \%$, copper by $19.6 \%$, and selenium by $27.7 \%$.

Conclusion. Research has shown that amaranth flour and non-steamed buckwheat flour are rich in potassium, magnesium, iron, copper and selenium. The samples under consideration exceed rice and corn in the content of all the microelements under consideration, with the exception of sodium.

Keywords: amaranth, balanced diet, children of preschool and school age, celiac disease, gluten-free products, grain-based products for baby food
\end{abstract}

For citation: Urubkov S.A., Khovanskaya S.S., Smirnov S.O. The content of certain minerals and trace elements in products made from amaranth and buckwheat flour for children with gluten intolerance. Vopr. det. dietol. (Pediatric Nutrition). 2020; 18(5): 49-53. DOI: 10.20953/1727-5784-2020-5-49-53

\section{Содержание некоторых минеральных веществ и микроэлементов в продуктах из амарантовой и гречневой муки для детей с непереносимостью глютена}

\author{
С.А.Урубков, С.С.Хованская, С.О.Смирнов \\ НИИ пищеконцентратной промышленности и специальной пищевой технологии - фрилиал ФГБУН «ФИЦ \\ питания, биотехнологии и безопасности пищи», Измайлово, Московская область, Российская Федерация
}

\begin{abstract}
Цель исследования. Определение содержания макро- и микроэлементов в гречневой и амарантовой муке, а также продуктах, полученных из смесей муки данных культур.

Материалы и методы. Исследовано содержание минеральных веществ (кальций, магний, калий, натрий, железо, медь, цинк, марганец, селен, кобальт, свинец, никель, молибден) в гречневой и амарантовой муке, а также продуктах, полу-
\end{abstract}

\author{
Для корреспонденции: \\ Урубков Сергей Александрович, кандидат технических наук, старший \\ научный сотрудник отдела детского и диетического питания Научно- \\ исследовательского института пищеконцентратной промышленности и \\ специальной пищевой технологии - филиал ФГБУН «ФИЦ питания, \\ биотехнологии и безопасности пищи" \\ Адрес: 142718, Московская область, Ленинский район, пос. Измайлово, 22 \\ Телесон: (495) 383-5874 \\ E-mail: glen.vniiz@ gmail.com \\ ORCID ID: https://orcid.org/0000-0002-2292-8649 \\ Статья поступила 09.09.2020 г., принята к печати 27.10.2020 г.
}

\section{For correspondence:}

Sergey A. Urubkov, candidate of technical sciences, senior research fellow department of children's and dietary nutrition, Scientific Research Institute of Food-concentrate Industry and Special Food Technology» - Branch «Federa Research Center of Nutrition and Biotechnology and Food safety

Address: 22 Izmailovo, Leninsky district, Moscow region, 142718, Russian Federation

Phone: (495) 383-5874

E-mail: glen.vniiz@gmail.com

ORCID ID: https://orcid.org/0000-0002-2292-8649

The article was received 09.09.2020, accepted for publication 27.10.2020 
ченных из смесей муки данных культур. Для определения содержания минеральных веществ в образцах применяли метод атомно-абсорбционной спектроскопии с электротермической атомизацией с модификатором матрицы палладий азотнокислый на атомно-абсорбционном спектрофотометре Hitachi 180-80.

Результаты. Получен экспериментальный материал по содержанию макро- и микроэлементов в безглютеновых продуктах. Значительную часть минеральных веществ рассматриваемых образцов муки составляет калий - 371 мг/100 г для амарантовой муки и 405 мг/100 г для гречневой муки. Высокое содержание магния обнаружено в гречневой муке 239,9 мг/100 г и 202,5 мг/100 г в амарантовой муке. Низкое содержание кальция отмечено в обоих исследуемых образцах: 69,0 мг/кг в амарантовой и 62,0 мг/кг в гречневой муке. Амарантовая мука превосходит гречневую муку по содержанию таких микроэлементов как медь (319 мкг/100 г), цинк (2495 мкг/100 г) и селен (515,4 мкг/100 г). Гречневая мука содержит больше калия (405,9 мг/100 г), магния (239,9 мг/100 г), а также меди (334 мкг/100 г) по сравнению с амарантовой мукой. Полученные данные показывают, что амарантовую и гречневую муку можно классифицировать как хорошие источники селена с содержанием 515,4 мкг/100 г и 404,0 мкг/100 г соответственно. Содержание минеральных веществ в блинчиках, приготовленных из смесей амарантовой муки и муки из нативной гречневой крупы, уменьшилось на 3-23\% от их содержания в исходной муке. Проведенный расчет удовлетворения рекомендуемой суточной потребности показал, что употребление порции блинчиков (45 г) детьми школьного возраста позволит удовлетворить их суточную потребность в среднем: в магнии на 35,3\%, в калии 9,5\%, в железе на 26,4\%, меди на 19,6\%, селене на 27,7\%.

Заключение. Амарантовая мука и мука из непропаренной гречневой крупы богаты калием, магнием, железом, медью и селеном. Данные образцы по содержанию всех рассматриваемых макроэлементов за исключением натрия превосходят рис и кукурузу.

Ключевые слова: амарант, безглютеновая продукция, дети старше трех лет, зерновые смеси, целиакия, продукты детского питания на зерновой основе, сбалансированная диета

Для цитирования: Урубков С.А., Хованская С.С., Смирнов С.О. Содержание некоторых минеральных веществ и микроэлементов в продуктах из амарантовой и гречневой муки для детей с непереносимостью глютена. Вопросы детской диетологии. 2020; 18(5): 49-53. DOI: 10.20953/17275784-2020-5-49-53

$\mathbf{U}$ ntil the end of the twentieth century, celiac disease was considered an extremely rare disease and therefore the etiology and pathogenesis of the disease were not studied for a long time. An important step in the diagnosis and treatment of this disease was the discovery of Detlef Schuppan with his team of researchers of a highly sensitive marker, which made it possible to conduct mass screening among the population, the results of which showed that previously considered a fairly rare disease exclusively in childhood, is one of the most common genetically determined conditions. In just 10 years, celiac disease has become a popular disease all over the world, with a steadily increasing prevalence rate currently estimated at $1-2 \%$ of the world's population [1].

Recent studies have shown that the prevalence of gluten intolerance is much higher than the generally accepted level of celiac disease $(0,5-2 \%)$ and is roughly estimated at $6 \%$ of the total population [2, 3]. The actual number of people suffering from gluten intolerance may be much higher, since the diagnosis of this disease is difficult.

Currently, the only treatment for gluten intolerance, including celiac disease, is a strict gluten-free diet. The toxic effect of gluten on the body does not weaken when processing proteins denaturation or enzymatic hydrolysis to peptides, which is the reason for the complete rejection of the use of products from cereals containing gluten, as well as products that contain «hidden» gluten used as part of a food additive in the production process $[4,5]$.

Mainly due to a decrease in the intake of grain-based products, children often have a deficiency of proteins and fats of plant origin, dietary fiber (fiber), as well As b vitamins and such important minerals as potassium, magnesium, selenium, etc. The lack of consumption of these food components causes violations of the child's physical development $[5,6]$.

The mineral elements contained in cereals are important for the growing child's body, since they participate in all biochemical processes (redox reactions, free radical oxidation, differentiation, tissue growth, etc.). They are also necessary for the biosynthesis of biologically active substances, participate in metabolism, and affect the activity of enzymes (as part of the catalytic centers of a number of enzymes or a competitive inhibitor of enzymes) and carrier proteins [7].

Selenium and its antioxidant and immunomodulatory properties play an important biological role for the body. Selenium is involved in redox reactions, respiratory chain reactions, pentose phosphate cycle, citric acid cycle and lipid peroxidation, regulation of cell growth and apoptosis, secretion and metabolism of thyroid hormones, and immune processes [8].

Rice and corn flour are the main ingredients in the production of gluten-free grain products worldwide, from which more than $85 \%$ of all products are produced. Rice is popular for its white color, neutral taste, high digestibility, and hypoallergenic properties. Corn is the second most commonly used raw material in the production of gluten-free products, and it gives the product a characteristic corn flavor and shade. Products from these crops have a high energy value, but have a low content of high-grade protein, polyunsaturated fatty acids, macro-and microelements, and dietary fiber. Buckwheat is also a gluten-free crop widely used in Russia, but the range of gluten-free products using buckwheat flour is very limited.

Thus, the goal of the study is not only to expand the range of products with acceptable levels of gluten (less than $20 \mathrm{mg} / \mathrm{kg}$ ), but also to improve their nutritional properties by ensuring a balanced diet. This problem can be solved by using buckwheat in the component composition of the developed products, as well as non - traditional raw materials for Russia-amaranth.

Buckwheat does not contain gluten, is characterized by high nutritional and biological value, is a source of vegetable protein, lipids, dietary fiber and vitamins $\mathrm{B}_{1}, \mathrm{~B}_{2}, \mathrm{PP}, \mathrm{B}_{6}, \mathrm{E}$, folacin and choline, as well as minerals, magnesium, potassium, phosphorus, iron, copper, etc., has unique qualities due to the presence of a number of compounds with antioxidant properties, as well as the ability to produce gluten-free products with a low glycemic index [9].

Amaranth does not contain gluten, and the amount of protein with a full set of amino acids is about $30 \%$ higher than that of 
traditional cereals. Amaranth protein is rich in essential amino acids: lysine, isoleucine, methionine, threonine, tryptophan, leucine, the content of which is several times higher than their amount in wheat, rice, oats and corn. Amaranth is a rich source of lipids, beta-carotene, vitamins, minerals, and dietary fiber. Amaranth is characterized by a high content of minerals such as potassium, magnesium, and selenium. In addition, world studies refer to amaranth as a source of biologically active compounds with antioxidant and antimicrobial properties, as well as antidiabetic, antihyperlipidemic and antihypercholesterolemic effects [10, 11].

Currently, the reference books of chemical composition used in Russia do not contain generalized data on the content of macro-and microelements in amaranth grain. This can be explained by the fact that this culture is relatively new in Russian food industry.

In connection with the above research on the content of mineral substances is relevant for the development of specialized gluten-free grain mixtures using amaranth for the nutrition of children with gluten intolerance [12].

The purpose of this work is to determine the content of macro-and microelements in buckwheat and amaranth flour, as well as products (pancakes) obtained from flour mixtures of these cultures.

\section{Materials and methods}

In this study, we used amaranth flour 1st grade TU 9293-00477872064-2011, the sort of «Voronezhskiy», Voronezh region

Buckwheat flour is produced on an industrial scale both from steamed cereals, i.e. hydrothermically processed, and from native (non-steamed) cereals. The process of grain processing, including steaming followed by drying and cooling, leads to a deterioration of the nutrient composition of cereals, in contrast to the native, where the main nutrients and vitamins are not affected by heat treatment, so the study used native buckwheat according to GOST R 55290-2012 (Grade 1), Altai region.
Flour from native buckwheat was produced by grinding in a laboratory mill (Retsch ZM-1) non-steamed buckwheat groats using the technology of milling varietal flour from cereals. The size of the resulting flour was controlled by sieves №045 according to TU 14-4-1374 (the remainder is not more than 5\%) and №43 PA-70 according to GOST 4403 (passage is not less than 50\%) according to TU 9293-005-00932169-96;

Mixtures of amaranth flour and native buckwheat flour were used in the preparation of pancakes. A mixture of amaranth flour and native buckwheat flour was taken in the ratio of 1:3 (Recipe №1) and 1:1 (Recipe №2), respectively. Flour mixtures were prepared by mixing the components in a laboratory mixer Gastromix B5.

To determine the mineral content in the samples, the method of atomic absorption spectroscopy with electrothermal atomization with a palladium nitric acid matrix modifier was used on a Hitachi $180-80$ atomic absorption spectrophotometer, according to GOST R 56372-2015. «Mixed feeds, concentrates and premixes. Determination of the mass fraction of iron, manganese, zinc, cobalt, copper, molybdenum and selenium by atomic absorption spectroscopy».

The mineral content of the samples was determined after wet mineralization of the samples in nitric and perchloric acids with the addition of hydrogen peroxide and ethanol in order to convert selenium from inorganic and organic forms to selenite ion. To analyze the studied amaranth grain, the weight of the sample was experimentally determined, which was about $3 \mathrm{~g}$. The content was determined in three repetitions.

\section{Results and discussion}

As a result of the study, data were obtained on the content of macro-and microelements in amaranth and buckwheat flour, as well as pancakes made from their mixture (table). Table 1 also shows the average data from the literature on the content of minerals in rice and corn flour [9, 13].

Table 1. Mineral content in gluten-free products

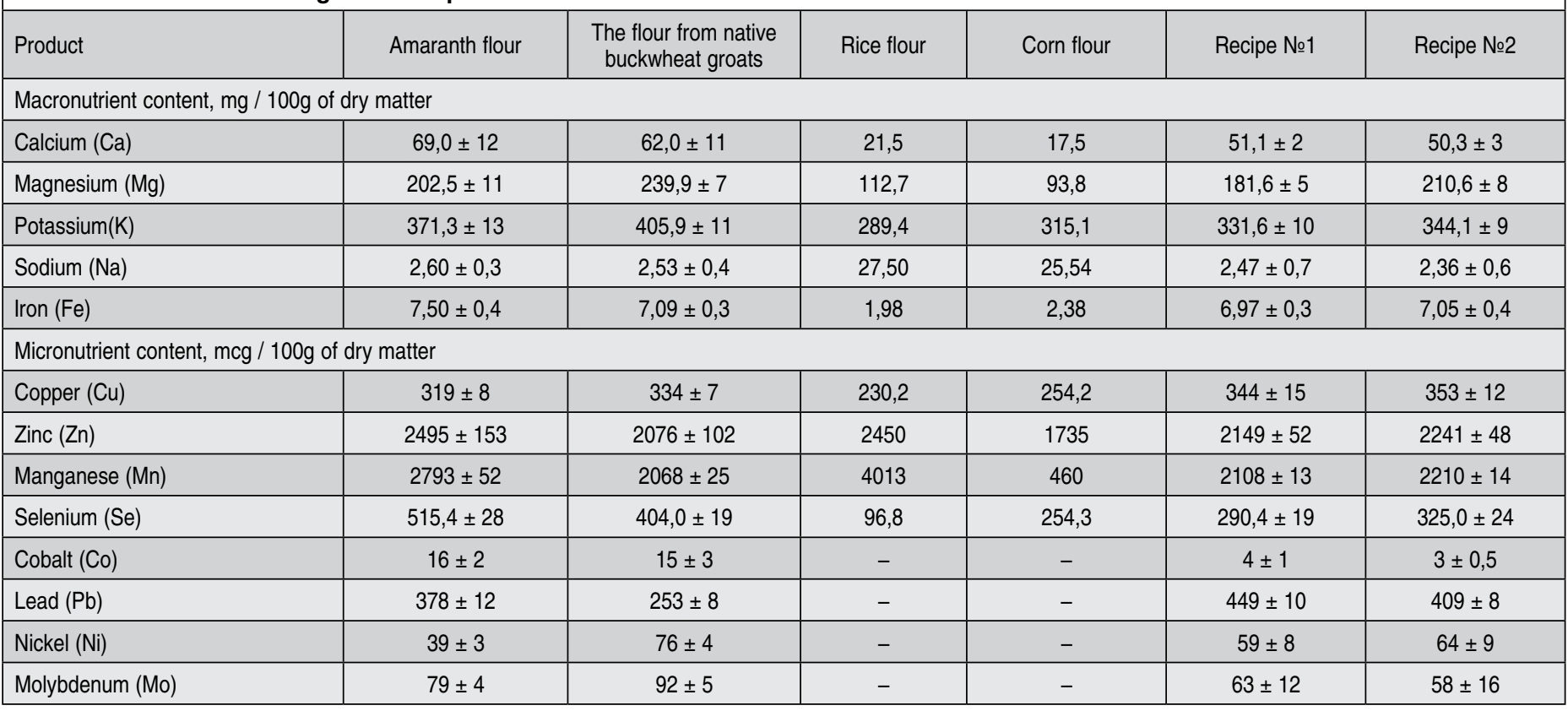


The results show that the potassium content in amaranth flour is $371 \mathrm{mg} / 100 \mathrm{~g}$, and in buckwheat flour- $405 \mathrm{mg} / 100 \mathrm{~g}$. Buckwheat flour showed a higher magnesium content of $239.9 \mathrm{mg} / 100 \mathrm{~g}$, compared to amaranth flour $-202.5 \mathrm{mg} / 100 \mathrm{~g}$. The low content of calcium in the studied samples is seen, which is a characteristic feature for grain crops. The iron content for amaranth flour was $7.50 \mathrm{mg} / 100 \mathrm{~g}$, for native buckwheat flour $-7.09 \mathrm{mg} / 100 \mathrm{~g}$. It can be noted that this level of iron content in amaranth and buckwheat flour is high for cereals and exceeds similar values of its content in rice and corn. Amaranth and buckwheat generally outperform compared gluten-free crops in macronutrient content with the exception of sodium. Amaranth flour is superior to other samples in terms of the content of such trace elements as selenium (515.4 mcg/100 g), copper (319 mcg/100 g) and zinc $(2495 \mathrm{mcg} / 100 \mathrm{~g})$. Other authors also characterize amaranth as a raw material with a high content of minerals $[14,15]$. The content of individual minerals in the flour from non-steamed buckwheat flour is comparable to their amount in amaranth flour. Buckwheat flour contains relatively little more potassium (405.9 mg/100 g), magnesium (239.9 mg/100 g), and copper $(334 \mathrm{mcg} / 100 \mathrm{~g})$.

The data obtained show that amaranth and buckwheat flour can be classified as good sources of selenium with a content of $515.4 \mathrm{mcg} / 100 \mathrm{~g}$ and $404.0 \mathrm{mcg} / 100 \mathrm{~g}$, respectively. High selenium content can also be traced in products obtained from mixtures of these crops - this is promising for their use as raw materials in the production of gluten-free products with a high selenium content, such as bakery products [16].

Baking results showed that heat treatment reduced the concentration of individual minerals in the finished product. The mineral content of pancakes made from mixtures of amaranth flour and native buckwheat flour decreased from 3 to $23 \%$.

Based on the content of minerals in the finished products, the calculation of the recommended daily requirement (RDR) of macro - and microelements for pancakes made from amaranth and buckwheat flour was made on the example of their consumption by school-age children (figure).

The average daily requirement of mineral substances for the child's body is accepted according to the norms of physiological needs for energy and food substances for various groups of the population of the Russian Federation [17]. Based on the

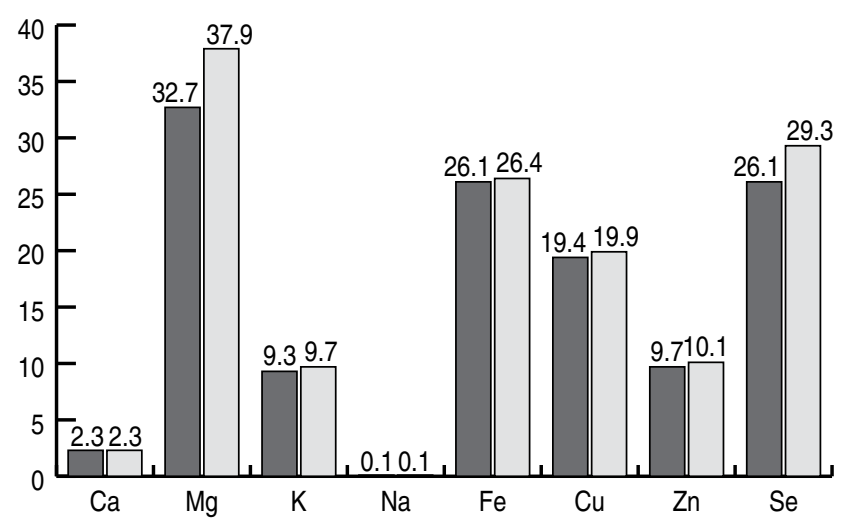

Pancake, Recipe №1 Pancake, Recipe №2

Figure. Meeting the recommended daily mineral needs of school-age children on the example of pancake consumption. recommended average daily set of products, the consumption of cereals for school-age children is $45 \mathrm{~g} /$ day [18].

The calculation showed that the use of a portion of pancakes (45 g) by school-age children will meet their daily needs on average: magnesium by $35.3 \%$, potassium by $9.5 \%$, iron by $26.4 \%$, copper by $19.6 \%$, selenium by $27.7 \%$. The low content of sodium in the analyzed raw materials caused a low percentage of satisfaction of the RDR of the finished product.

It is also necessary to note the high level of satisfaction of the body's RDR with selenium. The use of amaranth and buckwheat in gluten-free products will make up for the lack of selenium, as well as other vital micro - and macronutrients. Despite the low degree of iron assimilation from plant raw materials (on average $10 \%$ of its amount), its consumption from the products under consideration will have an impact on meeting the needs of the child's body, given the gluten - free diet and the reluctance to consume animal products (offal) sources of «heme» iron.

\section{Conclusion}

Gluten-free products for children with the inclusion of nonsteamed buckwheat and amaranth for children with gluten intolerance are new to the Russian market.

Research has shown that amaranth flour and non-steamed wheat flour are rich in potassium, magnesium, iron, copper and selenium. The samples under consideration exceed rice and corn in the content of all the macronutrients under consideration, with the exception of sodium.

When children of school age use pancakes (45 g) made from amaranth and buckwheat flour, the body's supply of magnesium is on average $35.3 \%$ of the daily norm, potassium - by $9.5 \%$ of the daily norm, iron - by $26.4 \%$ of the daily norm, copper - by $19.6 \%$ of the daily norm, selenium - by $27.7 \%$ of the daily norm.

Taking into account the high content of minerals in amaranth and buckwheat flour, the development of specialized products with their inclusion is a promising direction and will help to expand the taste diversity and improve the provision of nutrients to patients with various forms of gluten intolerance.

\section{Financial support}

The research work was carried out at the expense of subsidies for the state task in the framework of the Program of Fundamental research of the state academies of Sciences for 2019-2021 (theme № 0529-2019-0065). «Development of specialized gluten-free grain mixtures with amaranth to feed children with gluten intolerance».

\section{Conflict of interest}

The authors declare that there are no conflicts of interest.

\section{Gratitude}

The authors thank the laboratory of product quality and analytical research methods Scientific Research Institute of Food concentrate Industry and Special Food Technology" Branch «Federal Research Center of Nutrition and Biotechnology and Food safety» for the analysis. 


\section{References}

1. Schuppan D. Zöliakie. Pathogenese, Klinik, Epidemiologie, Diagnostik, Therapie [Celiac disease: Pathogenesis, clinics, epidemiology, diagnostics, therapy]. Bundesgesundheitsblatt Gesundheitsforschung Gesundheitsschutz. 2016 Jul;59(7):827-35. DOl: 10.1007/s00103-016-2364-1.

2. Bizzaro N, Tozzoli R, Villalta D, Fabris M, Tonutti E. Cutting-edge issues in celiac disease and in gluten intolerance. Clin Rev Allergy Immunol. 2012 Jun;42(3):27987. DOI: $10.1007 / \mathrm{s} 12016-010-8223-1$

3. Rostami Nejad M, Karkhane M, Marzban A, Nazemalhosseini Mojarad E, Rostami K. Gluten related disorders. Gastroenterol Hepatol Bed Bench. 2012 Winter;5(Suppl 1):S1-7.

4. Russian consensus on the diagnosis and treatment of celiac disease in children and adults. (In Russian).

5. Belmer SV, Khavkin Al. (eds.) Gastroenterology of children. Moscow: "Medpraktika-M" Publ., 2003. (In Russian).

6. Baby food. Edited by V.A.Tutelyan, I.Ya.Kon. Moscow: Meditsinskoe informatsionnoe agentstvo, 2017. (In Russian).

7. Korovina NA, Zakharova IN, Zaplatnikov AL, Obynochnaya EG. Correction of vitamin and mineral deficiency in children. Medical Council (Meditsinskiy sovet). 2013;8:94-8. (In Russian).

8. Skurikhin IM, Tutelyan VA. Tables of chemical composition and caloric content of Russian food products. Moscow, 2007. (In Russian).

9. Tutelyan VA, Knyazhev VA, Khotimchenko SA, Golubkina NA, Kushlinskii NE, Sokolov YaA. Selenium in the human body: metabolism, antioxidant properties, role in carcinogenesis. Moscow: RAMS Publishing House, 2002, 224 p. (In Russian).

10. Caselato-Sousa VM, Amaya-Farfán J. State of knowledge on amaranth grain: a comprehensive review. J Food Sci. 2012 Apr;77(4):R93-104. DOI: 10.1111/j.1750-3841.2012.02645.x

11. Martinez-Lopez A, Millan-Linares MC, Rodriguez-Martin NM, Millan F, Montserratde la Paz S. Nutraceutical value of kiwicha (Amaranthus caudatus L.). Journal of Functional Foods. 2019;103735. DOl: 10.1016/j.jff.2019.103735

12. Urubkov SA, Khovanskaya SS, Dremina NV, Smirnov SO. Grain-based products for baby food. Vopr. det. dietol. (Pediatric Nutrition). 2018;16(4):67-72. DOI: 10.20953/1727-5784-2018-4-67-72

13. United States Department of Agriculture. Food Data Central. Available at: https:// ndb.nal.usda.gov

14. Kiewlicz J, Rybicka I. Minerals and their bioavailability in relation to dietary fiber, phytates and tannins from gluten and gluten-free flakes. Food Chem. 2020 Feb 1;305:125452. DOI: 10.1016/j.foodchem.2019.125452
15. Vysochina Gl. Amaranth (Amaranthus L.): chemical composition and prospects of using. Chemistry of plant raw material. 2013;2:5-14.

16. Urubkov SA, Khovanskaya SS, Smirnov S0. Amaranth as a source of selenium in a gluten-free diet. Vopr. det. dietol. (Pediatric Nutrition). 2019;17(3):42-46. DOl: 10.20953/1727-5784-2018-4-67-72

17. Norms of physiological needs in energy and food substances for various groups of the population of the Russian Federation. Available at: https://www. rospotrebnadzor.ru/documents/details.php?ELEMENT_ID=4583 (In Russian).

18. Recommended average daily food packages for children aged 7-11 and 11-18. Available at: https://www.garant.ru/products/ipo/prime/doc/4085291/ (In Russian).

Information about co-authors:

Svetlana S. Khovanskaya, candidate of technical sciences, head of Department of of children's and dietary nutrition, Scientific Research Institute of Food-

concentrate Industry and Special Food Technology - Branch Federal Research

Center of Nutrition and Biotechnology and Food safety

Address: 22 Izmailovo, Leninsky district, Moscow region, 142718,

Russian Federation

Phone: (495) 383-5874

E-mail: khosveserg@yandex.ru

ORCID ID: https://orcid.org/0000-0002-2334-5242

Stanislav O. Smirnov, candidate of technical sciences, deputy director of Scientific Research Institute of Food-concentrate Industry and Special Food Technology Branch Federal Research Center of Nutrition and Biotechnology and Food safety Address: 22 Izmailovo, Leninsky district, Moscow region, 142718

Russian Federation

Phone: (495) 549-3820

E-mail: sts_76@bk.ru

ORCID ID: https://orcid.org/0000-0002-8073-1238

\section{Информация о соавторах:}

Хованская Светлана Сергеевна, кандидат технических наук, заведующая отделом детского и диетического питания Научно-исследовательского института пищеконцентратной промышленности и специальной пищевой технологии - филиал ФГБУН «ФИЦ питания, биотехнологии и безопасности пищи»

Адрес: 142718, Московская область, Ленинский район, пос. Измайлово, 22

Телесон: (495) 383-5874

E-mail: khosveserg@yandex.ru

ORCID ID: https://orcid.org/0000-0002-2334-5242

Смирнов Станислав Олегович, кандидат технических наук, заместитель директора по научной работе Научно-исследовательского института пищеконцентратной промышленности и специальной пищевой технологии филиал ФГБУН «ФИЦ питания, биотехнологии и безопасности пищи»

Адрес: 142718, Московская область, Ленинский район, пос. Измайлово, 22 Телефон: (495) 549-3820

E-mail: sts 76@bk.ru

ORCID ID: https://orcid.org/0000-0002-8073-1238

\section{НОВОСТИ МЕАИЦИНЫ}

\section{Непереносимость лактозы: современные подходы к диагностике и лечению}

Лекция посвящена непереносимости лактозы - клиническому проявлению лактазной недостаточности, являющейся врожденным или приобретенным состоянием и характеризующейся снижением активности расщепляющего молочный сахар лактозу фрермента лактазы в тонкой кишке. Заболевание может протекать скрыто или явно и выявляются, как правило, только манифестные случаи с фрормированием метаболических нарушений, задержкой развития или влияющие на социальную активность. 